\title{
APRESENTAÇÃO
}

\section{Dossiê 40 anos de educação pública}

Nos últimos 40 anos (1978-2018), a educação pública, nomeadamente a brasileira, sofreu um nefário processo de sucateamento e privatização, bastante agudizado nos anos 1990 a partir da última reforma do Estado, de caráter gerencial (BRESSER-PEREIRA, 1998). Um movimento de proletarização do professorado também é notório no referido intervalo de tempo, bem como a desvinculação da instituição escolar pública da sociedade e dos debates na respectiva esfera. Esses fatores, entre outros igualmente importantes, resultaram na fácil adesão da educação a um discurso tecnocrático, neoliberal e burocrático, predominante no contexto pós-Golpe.

O exposto cenário fez com que, a partir dos anos 1970, educadores e pesquisadores se organizassem em prol da universalização da escola pública de educação básica e aprofundassem o debate acerca dos currículos escolares das classes populares. Diversas conquistas alcançadas nessa direção, nos últimos anos, foram fruto dos espaços de discussão coletiva e da produção de material bibliográfico sobre esses e outros temas candentes da educação brasileira, como a qualidade e a formação inicial e continuada dos docentes da educação básica e superior.

Contudo, importantes desafios persistem. Especialmente no tocante ao tema qualidade, temos ainda um longo caminho a ser trilhado. Por se tratar de um conceito em disputa entre segmentos da sociedade organizada, em que prepondera uma concepção alinhada à eficiência produtiva, ainda não temos uma política pública que estabeleça sequer um padrão mínimo de qualidade. Incluída na meta 7 do Plano Nacional de Educação (PNE) 2014-2024, a oferta de uma educação de qualidade para todos ainda prescinde da definição de parâmetros para o financiamento e de indicadores para o acompanhamento dos gastos educacionais.

Fortemente conclamada em discursos difundidos globalmente, em que organismos multilaterais, dentre os quais o Banco Mundial (BM) e a Organização para a Cooperação e Desenvolvimento Econômico (OCDE), figuram como grandes 
mentores intelectuais das mudanças operadas na educação, a qualidade educacional tende a ser traduzida pelo Índice de Desenvolvimento da Educação Básica (Ideb), considerado pelo BM "[...] uma inovação jamais vista em nenhum outro grande país de regime federativo." (BANCO MUNDIAL, 2010, p. 11). Segundo a posição do Banco, a política de monitoramento da qualidade educacional implementada no Brasil é, em muitos aspectos, "[...] superior ao praticado atualmente no EUA e em outros países da OCDE." (BANCO MUNDIAL, 2010, p. 17).

Como sabemos, o Ideb é um indicador de avaliação das escolas públicas de educação básica constituído pela soma entre o resultado do desempenho dos estudantes na Prova Brasil e as taxas de rendimento escolar. Resulta, pois, do monitoramento de dados quantitativos. Logo, limita o conceito de qualidade ao que se pode aferir numericamente. Considerada por muitos especialistas em políticas educacionais uma compreensão reduzida de qualidade, impõe-se como desafio rever as políticas que hoje respondem pela qualidade educacional, mormente na educação básica.

Outro desafio a ser enfrentado, a despeito de outros igualmente importantes, é o da formação inicial e continuada dos professores da educação básica. Considerados pelos organismos multilaterais elementos-chave das reformas educacionais, os professores vêm ocupando a cena quando o assunto é a melhoria da qualidade educacional. Isso porque a compreensão dominante é a de que o problema da qualidade está relacionado com a formação dos professores, considerada distante da prática da sala de aula. Em se tratando da formação inicial, o esforço dos órgãos governamentais tem sido a implantação de uma Política Nacional de Formação dos Profissionais da Educação Básica, conforme dispõe o Decreto n. 8.752, de 09 de maio de 2016, que prevê a elaboração de um plano estratégico inicial para os professores que atuam nas escolas públicas do Brasil. Consubstanciado nessa política, foram implementados o Programa Institucional de Bolsas de Iniciação à Docência (Pibid) e o Programa de Residência Pedagógica.

Na educação superior, os desafios não são menores. Nos últimos 40 anos, o número de instituições a oferecer cursos de educação superior ampliou consideravelmente. Com isso, mais jovens e adultos estão tendo condições de acesso a um curso superior. No entanto, as desigualdades sociais e geopolíticas tendem a tornar ainda mais agudizadas as disparidades regionais. $\bigcirc$ problema 
da qualidade também impõe mudanças nos currículos, nas condições de acesso e permanência dos estudantes no ensino superior e na formação dos professores para atuação nesse nível de ensino.

Apontado de forma subliminar, esse quadro nos instiga ao debate e à reflexão sobre os desafios da educação brasileira. A delimitação do recorte temporal desse debate, no entanto, tem uma motivação bastante particular, qual seja, a comemoração de 40 anos da Revista Roteiro, a qual foi criada em 1978. O interesse em oferecer aos leitores um retrato da história da educação nesse período incitou a Comissão Editorial a lançar este Dossiê, que se compõe por um conjunto de 11 textos e uma resenha.

Os textos selecionados tocam em um amplo espectro de temas e questões atuais da histórica da educação brasileira nos últimos 40 anos. Esse espectro assinala algumas tendências em termos de fios condutores da discussão sobre a problemática da educação brasileira em período recente, no qual se entrelaçam questões como políticas públicas para a formação de tecnólogos; escola como a veem no contexto contemporâneo; cultura organizacional e trabalho docente; qualidade educacional; formação de professores; democratização das escolas; pedagogia popular; universalização da educação básica; e teorização curricular.

Além dos textos que integram o Dossiê, compõe esta edição especial da Roteiro um ensaio de autoria de Almerindo Janela Afonso. Na linha dos debates que está a travar há algum tempo sobre os efeitos do uso de dispositivos de accountability na educação, Afonso propõe uma instigante reflexão sobre dilemas e tensões que enfrentam os diretores de escolas portuguesas (agrupamentos, em Portugal). Conforme destaca o autor, porque as pressões recaem sobre demandas internas e externas, em Portugal, o diretor sofre a obrigação de uma accountability múltipla, cujo pilar mais visível é o da prestação de contas. $\bigcirc$ texto incita a continuidade dos debates sobre as formas que assumem os usos empíricos da accountabilty na educação.

Compõe esta edição, também, um conjunto formado por três artigos de demanda contínua. $\bigcirc$ primeiro, de autoria de Sandra Maria Zardo Morescho e Nadir Castilho Delizoicov, expõe um estudo sobre o Pacto Nacional 
pelo Fortalecimento do Ensino Médio (PNEM), por meio da percepção de orientadores do estudo do Pacto sobre a formação desenvolvida com professores de 10 escolas pertencentes à Gerência Regional de Chapecó, SC. O segundo, de autoria de Aline Madia Mantovani e Anderson dos Santos Carvalho, propõe uma discussão sobre a Educação de Jovens e Adultos (EJA), considerando-a uma política educacional dirigida à população jovem e adulta que pode ter tido a escolarização prejudicada pelo trabalho. Consoante argumentam, o que pode ter sido a razão do afastamento desses jovens do estudo, hoje, pode ser, contudo, fator de motivação para o retorno aos bancos escolares. Por fim, o último artigo desse conjunto tem como foco as narrativas das crianças do Movimento de Mulheres Camponesas (MMC) sobre práticas educativas realizadas no interior do Movimento. Constata-se que as narrativas das crianças expõem as contradições que perpassam as experiências formativas vivenciadas por elas no Movimento.

Desejo que os leitores e simpatizantes aproveitem o conteúdo e os temas aqui trazidos para empreender novos debates sobre velhos problemas da educação brasileira.

Boa leitura a todos.

Marilda Pasqual Schneider

Editora-chefe

\section{REFERÊNCIAS}

BANCO MUNDIAL. Achieving world class education in Brazil: the next agenda. Dec. 21 2010. Disponível em: <http://cenpec.org.br/biblioteca/educacao/estudos-e-pesquisas/achieving-world-class-education-in-brazil-the-next-agenda>. Acesso em: 15 jan. 2018.

BRESSER-PEREIRA, L. C. A reforma do Estado nos anos 90: lógica e mecanismos de controle. Lua Nova: Revista de Cultura e Política, n. 45, p. 49-96, 1998. 